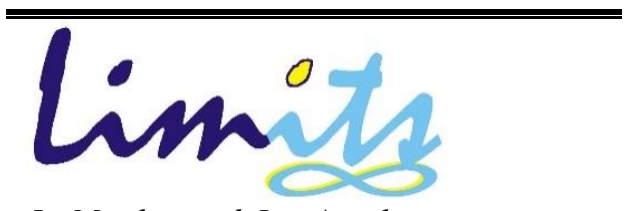

J. Math. and Its Appl.

ISSN: $1829-605 \mathrm{X}$

Vol. 12, No. 1, Mei 2015, 23-33

\title{
PENGGUNAAN PENYELESAIAN PERSAMAAN ALJABAR RICCATI WAKTU DISKRIT PADA KENDALI OPTIMAL LINIER KUADRATIK
}

\author{
Dita Marsa Yuanita ${ }^{1}$, Soleha $^{2}$ \\ 1,2Jurusan Matematika, Fakultas Matematika dan Ilmu Pengetahuan Alam, \\ Institut Teknologi Sepuluh Nopember (ITS) \\ Jl. Arief Rahman Hakim, Surabaya 60111 \\ seha_07@matematika.its.ac.id
}

\begin{abstract}
Abstrak
Permasalahan kendali optimal linier kuadratik adalah mendapatkan aturan kendali optimal $\boldsymbol{u}(\boldsymbol{t})$ dengan mendapatkan penyelesaian Persamaan Aljabar Riccati Waktu Diskrit (PRAWD) $\boldsymbol{P}(\boldsymbol{t})$ yang definit positif dan matriks gain umpan balik $\boldsymbol{K}(\boldsymbol{t})$. Untuk proses kendali berhingga, matriks-matriks $\boldsymbol{P}(\boldsymbol{t})$ dan $\boldsymbol{K}(\boldsymbol{t})$ adalah varian waktu. Akan tetapi, jika proses tersebut tidak berhingga maka matriks tersebut menjadi matriks konstan $\boldsymbol{P}$ dan $\boldsymbol{K}$. Untuk mendapatkan penyelesaian kendali optimal steady state, diperlukan suatu penyelesaian PRAWD steady state. Penyelesaian PRAWD steady state didapat dengan membalik waktu dari PRAWD non steady state. Pendiskritan juga diperlukan untuk menyelesaikan kendali optimal waktu diskrit apabila diberikan sistem waktu kontinu dengan indeks performansi kontinu, contoh kasus adalah sistem servo dengan plant pendulum terbalik. Analisis pada PRAWD menunjukkan sifat invariant dari PRAWD jika matriks pemberat indeks performansi diganti. Perlu diketahui juga bahwa PRAWD memiliki penyelesaian minimum yang unik.

Kata kunci: Kendali optimal linier kuadratik, Pendulum terbalik, Persamaan Aljabar Riccati waktu diskrit, Penyelesaian persamaan Aljabar Riccati waktu diskrit, Sistem servo
\end{abstract}

\section{Pendahuluan}

Sejak awal tahun 60-an, Kalman telah menjelaskan dalam jurnal-jurnal terdahulunya bahwa persamaan Aljabar Riccati memiliki peran krusial dalam penyelesaian masalah kendali optimal linier kuadratik, pemfilteran serta estimasi. Bahkan, pada 50 tahun terakhir persamaan Riccati ditemukan muncul dalam permasalahan linear dinamis dengan kriteria indeks performansi kuadratik, masalah faktorisasi spektral, teori perturbasi singular, teori stokastik realisasi dan identifikasi, 
masalah nilai batas untuk persamaan differensial biasa, teori embedding dan scattering invariant. Untuk alasan tersebut, persamaan Riccati secara universal dianggap sebagai landasan dari teori kendali modern.

Pada masalah kendali optimal, persamaan Aljabar Riccati muncul pada beberapa permasalahan yaitu masalah optimal kuadratik, Kalman Filter, $H_{2}$ dan $H_{\infty}$. Penelitian sebelumnya [1], memberikan salah satu bahasan pada kendali optimal yang memunculkan persamaan Aljabar Riccati yaitu masalah optimal kuadratik pada sistem yang berupa persamaan differensial yang memenuhi sifat kelinieran, atau disebut sistem linier invariant waktu kontinu. Permasalahan tersebut diselesaikan dengan mengoptimalkan indeks performansi menggunakan penyelesaian persamaan Aljabar Riccati waktu kontinu. Penyelesaian dapat diperoleh apabila sistem dalam keadaan terkontrol dan stabil.

Dengan cara sama, penyelesaian persamaan Aljabar Riccati waktu diskrit (PRAWD) berbentuk

$$
P=Q+F^{*} P F-F^{*} P G\left(R+G^{*} P G\right)^{-1} G^{*} X F
$$

dengan $P$ matriks definit positif, digunakan untuk mendapatkan penyelesaian dari permasalahan kendali optimal linier kuadratik waktu diskrit. Sistem waktu diskrit berbentuk persamaan beda

$$
x(t+1)=F x(t)+G u(t), \quad x(0)=c
$$

Dan asumsikan sistem terkontrol.

Permasalahan kendali optimal kuadratik waktu diskrit adalah mendapatkan vektor $u(t)$ sedemikian hingga indeks performansi kuadratik yang diberikan dapat diminimalkan menggunakan aturan umpan balik

$$
u(t)=-K x(t)
$$

dengan $K$ adalah matriks invarian waktu apabila proses kendali optimal tak berhingga. Misal diberikan salah satu contoh indeks performansi kuadratik

$$
J=\sum_{t=0}^{\infty}\left[x^{*}(t) Q x(t)+u^{*}(t) R u(t)\right]
$$

Matriks $Q$ dan $R$ secara terurut, adalah matriks Hermit (simetris) definit positif. Matriks tersebut merupakan pemberat dari vektor keadaan $x(t)$, dan vektor kendali $u(k)$. Diasumsikan bahwa vektor kendali $u(t)$ tidak memiliki kendala.

Pada tugas akhir ini, diberikan salah satu bahasan pada kendali optimal yang memunculkan persamaan Aljabar Riccati yakni masalah optimal kuadratik dari sistem (1.2) yaitu kendali optimal kuadratik waktu diskrit, kemudian kendali optimal kuadratik waktu diskrit pada keadaan steady state, dengan contoh kasus pada sistem pendulum terbalik mengenai penyelesaian PRAWD

\section{Sistem Pendulum Tebalik}

Proses-proses kimiawi, mekanik, elektronik dan lain-lain dapat dimodelkan dengan suatu sistem yang dapat direpresentasikan sebagai berikut

$$
\begin{aligned}
& x(t+1)=F x(t)+G u(t), \quad x(0)=x_{0} \\
& y(t)=C x(t)+D u(t)
\end{aligned}
$$

Persamaan ini disebut sistem linier invariant waktu diskrit. Persamaan (2.1) disebut persamaan keadaan. Persamaan (2.2) disebut persamaan output.

Vektor $x(t)$ adalah vektor keadaan pada waktu $t$. Vektor $u(t)$ adalah vektor input bebas linier dari sistem. Vektor $y(t)$ adalah output dari sistem. Matriks $F \in$ $M_{n \times n}, G \in M_{n \times r}, C \in M_{r \times n}$ dan $D \in M_{r \times m}$ adalah matriks yang mengandung parameter dari keseluruhan sistem. 
Sistem di atas memiliki sifat linier dan invariant waktu. Linier artinya untuk suatu operator $T$ berlaku jika input $u_{1}(t)$ memiliki output $y_{1}(t)$ dan $u_{2}(t)$ memiliki output $y_{2}(t)$, maka

$$
T\left(\alpha u_{1}(t)+\beta u_{2}(t)\right)=\alpha y_{1}(t)+\beta y_{2}(t)=\alpha T\left(u_{1}(t)\right)+\beta T\left(u_{2}(t)\right)
$$

Sedangkan invariant waktu berarti jika input $u(t)$ menghasilkan output $y(t)$, maka $u(t-\tau)$ menghasilkan output $y(t-\tau)$ untuk setiap $\tau \in \mathbb{Z}$. [4]

Dalam paper ini, akan diberikan salah satu sistem yang dapat diselesaikan dengan persamaan Riccati, yakni pendulum terbalik.

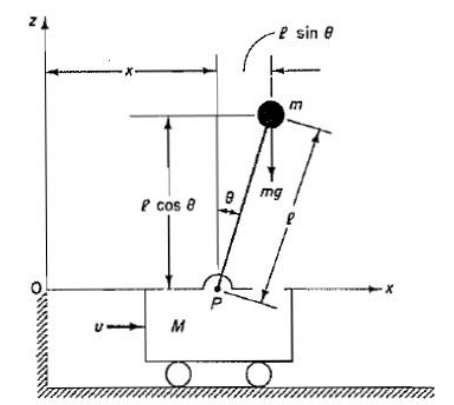

Gambar 1. Pendulum terbalik

Pendulum terbalik adalah pendulum yang porosnya ditempelkan pada kereta yang dapat bergerak dengan arah horizontal. Kereta digerakkan oleh suatu motor kecil yang pada saat $t$, bekerja suatu gaya $u(t)$ pada kereta. Gaya tersebut adalah variabel input pada sistem. Massa kereta dinotasikan dengan $M$, sedangkan $m$ adalah massa pendulum. Jarak antara titik poros pendulum ke pusat gravitasi massa adalah $l$. Sudut yang dibentuk oleh pendulum dengan sumbu vertikal adalah $\theta$. Sudut tersebut selalu diasumsikan bernilai kecil untuk menjaga pendulum terbalik tetap vertikal. $\left(x_{G}, z_{G}\right)$ menyatakan koordinat $(x, z)$ dari pusat gravitasi. Maka,

$$
\begin{aligned}
x_{G} & =x+l \sin \theta \\
z_{G} & =l \cos \theta
\end{aligned}
$$

Dengan menggunakan hukum kedua Newton, persamaan gerak pendulum pada arah sumbu $x$ sebagai berikut

$$
\begin{aligned}
& M \frac{d^{2} x}{d t^{2}}+m \frac{d^{2} x_{G}}{d t^{2}}=u, \\
& (M+m) \frac{d^{2}}{d t^{2}}(x+l \sin \theta)=u,
\end{aligned}
$$

Persamaan (2.3) dapat ditulis sebagai berikut

$$
(M+m) \ddot{x}-m l(\sin \theta) \dot{\theta}^{2}+m l(\cos \theta) \ddot{\theta}=u
$$

Kemudian, persamaan gerak massa $m$ pada arah $z$ didapat dengan menggunakan hukum kedua Newton untuk gerak melingkar sehingga

$$
\begin{array}{r}
m \frac{d^{2} x_{G}}{d t^{2}}(l \cos \theta)-m \frac{d^{2} z_{G}}{d t^{2}}(l \sin \theta)=m g l \sin \theta, \\
m \ddot{x} \cos \theta+m l \ddot{\theta}=m g \sin \theta
\end{array}
$$

Dengan melakukan pendekatan untuk $\sin \theta=\theta, \cos \theta=1$, dan $\theta \ddot{\theta}=0$, persamaan (2.4) dan (2.5) dapat dilinierisasi menjadi

$$
\begin{aligned}
& (M+m) \ddot{x}+m l \ddot{\theta}=u \\
& m \ddot{x}+m l \ddot{\theta}=m g \theta
\end{aligned}
$$

Linierisasi tersebut berlaku selama $\theta$ dan $\theta$ bernilai kecil. Persamaan (2.6) dan (2.7) mendefinisikan suatu model matematika dari sistem pendulum terbalik. 
Didefinisikan variabel keadaan sebagai berikut

$$
\begin{aligned}
& x_{1}=\theta \\
& x_{2}=\dot{\theta} \\
& x_{3}=x \\
& x_{4}=\dot{x}
\end{aligned}
$$

$x$ adalah lokasi dari kereta, sehingga $x$ merupakan output dari sistem, dapat ditulis

$$
y=x=x_{3}
$$

Dari persamaan (2.6) dan (2.7) didapat bentuk persamaan matriks-vektornya

$$
\begin{aligned}
{\left[\begin{array}{l}
\dot{x}_{1} \\
\dot{x}_{2} \\
\dot{x}_{3} \\
\dot{x}_{4}
\end{array}\right] } & =\left[\begin{array}{cccc}
0 & 1 & 0 \\
\frac{M+m}{M l} g & 0 & 0 & 0 \\
0 & 0 & 0 & 1 \\
-\frac{m}{M} g & 0 & 0 & 0
\end{array}\right]\left[\begin{array}{l}
x_{1} \\
x_{2} \\
x_{3} \\
x_{4}
\end{array}\right]+\left[\begin{array}{c}
0 \\
-\frac{1}{M l} \\
0 \\
\frac{1}{M}
\end{array}\right] u \\
y & =\left[\begin{array}{llll}
0 & 0 & 1 & 0
\end{array}\right]\left[\begin{array}{l}
x_{1} \\
x_{2} \\
x_{3} \\
x_{4}
\end{array}\right]
\end{aligned}
$$

Persamaan (2.8) dan (2.9) memberikan salah satu representasi ruang keadaan dari sistem pendulum terbalik.

\subsection{Desain Sistem Servo}

Pada bagian ini, akan dijelaskan mengenai masalah pendekatan penempatan pole pada desain dari sistem servo.

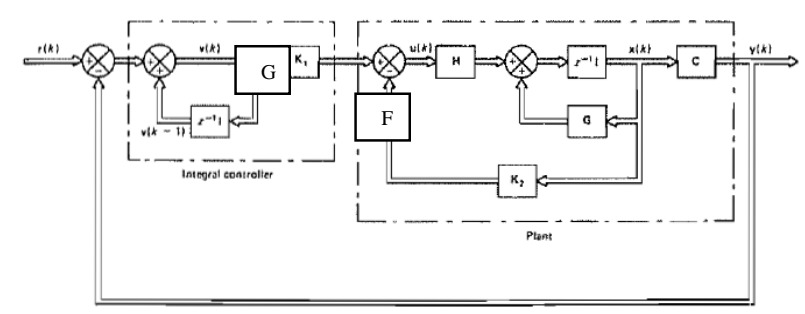

Gambar 2. Denah Sistem Servo

Gambar 2 menunjukkan konfigurasi antara suatu sistem servo dengan keadaan umpan balik dan kontroler integral. Dari gambar tersebut didapat

$$
\begin{gathered}
x(t+1)=F x(t)+G u(t) \\
y(t)=C x(t)
\end{gathered}
$$

Persamaan keadaan integratornya adalah

$$
v(t)=v(t-1)+r(t)-y(t)
$$

Vektor kendali $u(k)$ diberikan oleh

$$
u(t)=-K_{2} x(t)+K_{1} v(t)
$$

Desain sistem servo adalah menentukan matriks $K_{1}$ dan $K_{2}$ sedemikian hingga sistem memiliki pole loop tertutup yang diinginkan.

Perhatikan bahwa $u(t)$ adalah kombinasi linier dari vektor keadaan $x(t)$ dan $v(t)$, definisikan suatu vektor keadaan baru yang mengandung $x(t)$ dan $u(t)$. Kemudian didapat dari (2.10) dan (2.12) persamaan berikut

$\left[\begin{array}{l}x(t+1) \\ u(t+1)\end{array}\right]=\left[\begin{array}{cc}F & G \\ K_{2}-K_{2} F-K_{1} C F & I-K_{2} G-K_{1} C G\end{array}\right]\left[\begin{array}{l}x(t) \\ u(t)\end{array}\right]+\left[\begin{array}{c}0 \\ K_{1}\end{array}\right] r(t+1)$

Persamaan output, (2.11), dapat ditulis sebagai berikut 


$$
y(t)=\left[\begin{array}{ll}
C & 0
\end{array}\right]\left[\begin{array}{l}
x(t) \\
u(t)
\end{array}\right]
$$

Untuk persamaan berikutnya, didefinisikan vektor $r(t)$ adalah vektor konstan $r$. Dan didefinisikan vektor error sebagai berikut

$$
\begin{aligned}
& x_{E}(t)=x(t)-x(\infty) \\
& u_{E}(t)=u(t)-u(\infty)
\end{aligned}
$$

Perhatikan bahwa, untuk input $x(t), u(t)$, dan $v(t)$ mencapai nilai konstan pada $x(\infty), u(\infty)$, dan $v(\infty)$. Jadi, dari persamaan (2.13), didapatkan persamaan representasi errornya berupa

$$
\left[\begin{array}{l}
x_{E}(t) \\
u_{E}(t)
\end{array}\right]=\left[\begin{array}{cc}
F & G \\
K_{2}-K_{2} F-K_{1} C F & I-K_{2} G-K_{1} C G
\end{array}\right]\left[\begin{array}{l}
x_{E}(t) \\
u_{E}(t)
\end{array}\right]
$$

Persamaan (2.14) dapat ditulis sebagai

jika didefinisikan

$$
\left[\begin{array}{l}
x_{E}(k+1) \\
u_{E}(k+1)
\end{array}\right]=\left[\begin{array}{ll}
F & G \\
0 & 0
\end{array}\right]\left[\begin{array}{l}
x_{E}(k) \\
u_{E}(k)
\end{array}\right]+\left[\begin{array}{l}
0 \\
I
\end{array}\right] w(t)
$$

Kemudian definisikan juga

$$
w(t)=\left[K_{2}-K_{2} F-K_{1} C F \quad \vdots \quad I-K_{2} G-K_{1} C G\right]\left[\begin{array}{l}
x_{E}(t) \\
u_{E}(t)
\end{array}\right]
$$

$$
\begin{aligned}
& \xi(t)=\left[\begin{array}{l}
x_{E}(t) \\
u_{E}(t)
\end{array}\right], \quad \hat{F}=\left[\begin{array}{ll}
F & G \\
0 & 0
\end{array}\right], \quad \hat{G}=\left[\begin{array}{l}
0 \\
I
\end{array}\right] \\
& \widehat{K}=-\left[K_{2}-K_{2} F-K_{1} C F \quad \vdots \quad I-K_{2} G-K_{1} C G\right]:
\end{aligned}
$$

Sehingga persamaan (2.15) menjadi

Perhatikan bahwa

$$
\begin{gathered}
\xi(t+1)=\hat{F} \xi(t)+\widehat{G} w(t) \\
w(t)=-\widehat{K} \xi(t)
\end{gathered}
$$

$$
\left[\begin{array}{ccc}
K_{2} & \vdots & K_{1}
\end{array}\right]\left[\begin{array}{cc}
F-I & G \\
C F & C G
\end{array}\right]=\widehat{K}+\left[\begin{array}{ccc}
0 & \vdots & I
\end{array}\right]
$$

Matriks $K_{1}$ dan $K_{2}$ yang diinginkan dapat diperoleh dari persamaan (2.16).

\subsection{Kendali Optimal Linier Kuadratik}

Pada bagian ini dianalisis mengenai hubungan kendali optimal linier kuadratik dengan penyelesaian PRAWD. Sebelumnya, pandang suatu sistem terkontrol

$$
x(t+1)=F x(t)+G u(t), \quad x(0)=c
$$

dengan $t=0,1,2, \ldots, N-1$. Akan ditentukan vektor $u(t)$ sehingga indeks performansi kuadratik yang diberikan dapat diminimalkan. Misal diberikan indeks performansi kuadratik untuk waktu terbatas adalah

$$
J=x^{*}(N) S x(N)+\sum_{t=0}^{N-1}\left[x^{*}(t) Q x(t)+u^{*}(t) R u(t)\right]
$$

dengan $S \in M_{n \times n}, Q \in M_{n \times n}$, dan $R \in M_{r \times r}$ adalah matriks simetris (Hermit) definit (semidefinit positif). Permasalahan kendali optimal pada bagian ini diselesaikan dengan menggunakan pengali Lagrange $\lambda(1), \lambda(2), \ldots, \lambda(N)$. Kemudian dapat didefinisikan Indeks Performansi:

$$
\begin{gathered}
L=x^{*}(N) S x(N)+\sum_{t=0}^{N-1}\left[\left\{x^{*}(t) Q x(t)+u^{*}(t) R u(t)\right\} \lambda^{*}(t+1)\{F x(t)+G u(t)\right. \\
\left.-x(t+1)\}+\{F x(t)-G u(t)-x(t+1)\}^{*} \lambda(t+1)\right]
\end{gathered}
$$

Untuk meminimalkan fungsi $L, L$ didiferensialkan terhadap $\bar{x}(t), \bar{u}(t)$ dan $\bar{\lambda}(t)$ dengan hasil sama dengan 0 . 


$$
\begin{aligned}
& \frac{\delta L}{\delta \bar{x}(t)}=0 ; \lambda(t)=Q x(t)+F^{*} \lambda(t+1) \\
& \frac{\delta L}{\delta \bar{x}(N)}=0 ; \quad S x(N)=\lambda(N) \\
& \frac{\delta L}{\delta \bar{u}(t)}=0 ; \quad u(t)=-R^{-1} G^{*} \lambda(t+1) \\
& \frac{\delta L}{\delta \bar{\lambda}(t)}=0 ; \quad x(t+1)=F x(t)+G u(t)
\end{aligned}
$$

Vektor $u(t)$ dapat ditemukan dari persamaan

$$
u(t)=-K(t) x(t)
$$

matriks $K(t)$ adalah matriks anggota $M_{r \times n}$.

Asumsikan $\lambda(t)$ sebagai fungsi dari vektor keadaan $x(t)$ dalam bentuk berikut:

$$
\lambda(t)=P(t) x(t)
$$

$P(t)$ adalah matriks Hermit (real simetris) anggota $M_{n \times n}$ didapat

Dengan menyelesaikan persamaan (2.17) sampai (2.20) secara simultan

$P(t)=Q+F^{*} P(t+1) F-F^{*} P(t+1) G\left[R+G^{*} P(t+1) G\right]^{-1} G P(t+1) F$

Persamaan (2.21) disebut juga persamaan Riccati dengan $X(N)=S$. Persamaan (2.21) bisa diselesaikan secara mundur dari $t=N$ ke $t=0$ sampai didapat nilai yang konstan. Dari persamaan (2.21), vektor kendali optimal menjadi:

dengan

$$
u(t)=-\left[R+G^{*} P(t+1) G\right]^{-1} G^{*} P(t+1) F x(t)
$$

matriks $K(t)$ dinamakan matriks umpan balik.

$$
K(t)=\left[R+G^{*} P(t+1) G\right]^{-1} G^{*} P(t+1) F
$$

Kemudian, dicari nilai minimum dari indeks performansi

$\min J=\min \left\{x^{*}(N) S x(N)+\sum_{t=0}^{N-1}\left[x^{*}(t) Q x(t)+u^{*}(t) R u(t)\right]\right\}$

dengan mensubtitusikan persamaan yang telah didapatkan pada bagian sebelumnya.

$$
x^{*}(t) Q x(t)+u^{*}(t) R u(t)=x^{*}(t) P(t) x(t)-x^{*}(t+1) P(t+1) x(t+1)
$$

Dengan mensubtitusikan persamaan (2.23) ke persamaan indeks performansi $J$, diperoleh

$$
\begin{aligned}
J_{\min } & =x^{*}(N) S x(N)+\sum_{t=0}^{N-1}\left[x^{*}(t) P(t) x(t)-x^{*}(t+1) P(t+1) x(t+1)\right] \\
& =x^{*}(N) S x(N)+x^{*}(0) P(0) x(0)-x^{*}(N) P(N)
\end{aligned}
$$

Ingat bahwa $X(N)=S$, sehingga nilai minimum dari indeks performansi $J$ adalah

$$
J_{\min }=x^{*}(0) P(0) x(0)
$$

\subsection{Penyelesaian PRAWD}

Setelah mengetahui bentuk dari penyelesaian persamaan Aljabar Riccati, berikut ini diberikan teorema mengenai keberadaan dan keunikan penyelesaian Aljabar Riccati. Terlebih dahulu, definisikan persamaan Aljabar Riccati waktu diskrit sebagai fungsi berikut

$$
\mathcal{D}(P)=P-F^{*} P F+\left(S+G^{*} P F\right)^{*}\left(R+G^{*} P G\right)^{-1}\left(S+G^{*} P F\right)-Q=0
$$

dengan matriks $F \in \mathbb{C}^{n \times n}, S \in \mathbb{C}^{m \times n}, G \in \mathbb{C}^{n \times m}, R=R^{*} \in \mathbb{C}^{m \times m}, Q=Q^{*} \in \mathbb{C}^{m \times m}$. 
Suatu matriks $P \in \mathbb{C}^{n \times n}$ disebut penyelesaian dari $\mathcal{D}(P)$ apabila $P$ merupakan matriks Hermit, $\operatorname{det}\left(R+G^{*} P G\right) \neq 0$ dan $\mathcal{D}(P)=0$. Sehingga didapat vektor kendali optimal

$$
u_{o p t}(t)=\left[F-G\left(R+G^{*} P_{o p t} G\right)^{-1}\left(S+G^{*} P_{o p t} F\right)\right] x(t)
$$

yang akan meminimumkan indeks performansi

$$
J\left(x_{0}, u\right)=\sum_{t=0}^{\infty}\left(x^{*}(t) \quad u^{*}(t)\right)\left(\begin{array}{ll}
Q & S^{*} \\
S & R
\end{array}\right)\left(\begin{array}{l}
x(t) \\
u(t)
\end{array}\right)
$$

dengan $J$ semidefinit positif. Indeks performansi optimal diberikan oleh

$$
J_{o p t}=x_{0}^{*} P_{o p t} x_{0}
$$

$P_{\text {opt }}$ adalah penyelesaian semidefinit terkecil dari persamaan Aljabar Riccati waktu diskrit dan $x(0)=x_{0}$.

Serta definisikan suatu matriks loop tertutup terkait penyelesaian $P$ dari (2.25)

$$
F_{P}=F-G\left(R+G^{*} P G\right)^{-1}\left(S+G^{*} P F\right)
$$

dan $\sigma\left(F_{P}\right)$ adalah himpunan seluruh nilai eigen yang berbeda dari $F_{P}$. Maka keadaan optimal memenuhi $x(t+1)=\left(F_{P_{\text {opt }}}\right) x(t)$.

Suatu penyelesaian $P$ dikatakan sebagai penstabil jika $|\lambda|<1$ untuk seluruh nilai eigen $\lambda$ dari $F_{P}$.

Misal $\mathbb{D}=\{z ;|z|<1\}$ adalah unit disk terbuka dan $\delta \mathbb{D}=\{z ;|z|=1\}$ adalah unit circle.

\section{Hasil dan Pembahasan}

\subsection{Kendali Optimal Kuadratik Steady State}

Pada bagian ini diberikan kasus ketika proses kendali tidak berhingga atau $N=$ $\infty$, sehingga matiks gain varian waktu $K(t)$ menjadi suatu matriks konstan $K$. Serta matriks penyelesaian PRAWD $P(t)$ menjadi $P$.

Pandang persamaan (1.2)

dengan $F=\left[\begin{array}{cc}0 & 0 \\ -0.5 & 1\end{array}\right], G=\left[\begin{array}{l}1 \\ 0\end{array}\right]$, nilai awal $x(0)=\left[\begin{array}{l}2 \\ 2\end{array}\right]$, serta indeks performansi yang akan diminimumkan

$$
J=\sum_{t=0}^{\infty}\left[x^{*}(t)\left[\begin{array}{cc}
1 & 0 \\
0 & 0.5
\end{array}\right] x(t)+u^{*}(t) u(t)\right]
$$

Bentuk $x^{*}(N) S x(N)$ tidak ada di persamaan (3.4) dikarenakan jika sistem stabil maka $x(\infty)$ bernilai nol sehingga $x^{*}(\infty) S x(\infty)=0$.

Salah satu cara untuk menyelesaikan persamaan Riccati untuk kendali optimal steady state adalah dengan membalik waktu dari persamaan Riccati non steady state pada persamaan (1.1) menjadi

$$
P(t+1)=Q+F^{*} P(t) F-F^{*} P(t) G\left[R+G^{*} P(t) G\right]^{-1} G P(t) F
$$

dan iterasi persamaan tersebut dengan MATLAB mulai dari $P(0)=0$ hingga $P$ mencapai nilai konstan dengan syarat batas

dan menghasilkan nilai yang tetap yaitu

$$
P=\left[\begin{array}{ll}
0 & 0 \\
0 & 0
\end{array}\right]
$$

$$
P=\left[\begin{array}{cc}
1.5664 & -1.1328 \\
-1.1328 & 2.7556
\end{array}\right]
$$

Kemudian, matriks gain steady state $K$ dapat ditentukan dari persamaan (2.22) dapat diperoleh nilai $K=\left[\begin{array}{ll}0.2207 & -0.4414\end{array}\right]$ 
Indeks performansi $J$ yang bersesuaian dengan aturan kendali optimal steady state didapat dari persamaan (2.24) dengan mensubtitusikan $P$ untuk $P(0)$

$$
J_{\text {min }}=\left[\begin{array}{ll}
2 & 2
\end{array}\right]\left[\begin{array}{cc}
1.5664 & -1.1328 \\
-1-1328 & 2.7556
\end{array}\right]\left[\begin{array}{l}
2 \\
2
\end{array}\right]=8.2656
$$

\subsection{Kendali Optimal Kuadratik dari Sistem Servo}

Diinginkan untuk mendapatkan model ruang keadaan kontinu kemudian mendiskritkan model tersebut sehingga didapat model diskrit. Misalkan diketahui

$$
M=2.5 \mathrm{~kg}, \quad m=0.25 \mathrm{~kg}, \quad l=2 m
$$

Pada bab 2 didapat representasi ruang keadaan dari pendulum terbalik pada persamaan (2.8) dan (2.9). Subtitusikan nilai dari $M, m, l$ dan $g=9.81$ didapat persamaan keadaan dan output dari pendulum terbalik adalah

$$
\begin{gathered}
{\left[\begin{array}{l}
\dot{x}_{1} \\
\dot{x}_{2} \\
\dot{x}_{3} \\
\dot{x}_{4}
\end{array}\right]=\left[\begin{array}{cccc}
0 & 1 & 0 & 0 \\
5.3955 & 0 & 0 & 0 \\
0 & 0 & 0 & 1 \\
-0.981 & 0 & 0 & 0
\end{array}\right]\left[\begin{array}{l}
x_{1} \\
x_{2} \\
x_{3} \\
x_{4}
\end{array}\right]+\left[\begin{array}{c}
0 \\
-0.2 \\
0 \\
0.4
\end{array}\right] u} \\
y=\left[\begin{array}{llll}
0 & 0 & 1 & 0
\end{array}\right]\left[\begin{array}{l}
x_{1} \\
x_{2} \\
x_{3} \\
x_{4}
\end{array}\right]
\end{gathered}
$$

Untuk mendisain sistem kendali, diperlukan suatu model terdiskritisasi. Persamaan sistem terdiskritisasi adalah

$$
x(k+1)=e^{A} x(k)+\frac{B}{A}\left(e^{A}-1\right) u(k)
$$

Pendiskritan juga dapat dilakukan dengan menggunakan command pada MATLAB. Perintah ini digunakan untuk mendiskritkan suatu sistem linier invariant waktu kontinu, dengan dimisalkan periode sampel adalah $T=0.1$ detik

$$
[F, G]=c 2 d(A, B, T)
$$

Sehingga, model ruang keadaan terdiskritisasi adalah

$$
\begin{gathered}
x(t+1)=F x(t)+G u(t) \\
y(t)=C x(t)+D u(t)
\end{gathered}
$$

dengan

$F=\left[\begin{array}{cccc}1.0271 & 0.1009 & 0 & 0 \\ 0.5444 & 1.0271 & 0 & 0 \\ -0.0049 & -0.0002 & 1 & 0.1 \\ -0.0990 & -0.0049 & 0 & 1\end{array}\right], G=\left[\begin{array}{c}-0.0005 \\ -0.0101 \\ 0.002 \\ 0.04\end{array}\right], C=\left[\begin{array}{llll}0 & 0 & 1 & 0\end{array}\right]$, dan $D=0$

Berikutnya adalah mendisain sistem servo dari sistem pendulum terbalik. Disain sistem servo adalah menentukan matriks $K$ dan konstanta $K_{1}$ sedemikian hingga sistem memiliki pole loop tertutup yang diinginkan. Persamaan integrator ditunjukkan oleh persamaan (2.10) sehingga diperoleh

$$
\left[\begin{array}{l}
x(t+1) \\
v(t+1)
\end{array}\right]=\left[\begin{array}{cc}
F & 0 \\
-C F & 1
\end{array}\right]\left[\begin{array}{l}
x(t) \\
v(t)
\end{array}\right]+\left[\begin{array}{c}
G \\
-C G
\end{array}\right] u(t)+\left[\begin{array}{l}
0 \\
1
\end{array}\right] r(t+1)
$$

Misalkan $r$ adalah fungsi tangga dan definisikan

$$
\begin{aligned}
& x_{E}(t)=x(t)-x(\infty) \\
& v_{E}(t)=v(t)-v(\infty)
\end{aligned}
$$

Dapat diperoleh persamaan error seperti berbentuk

dengan

$$
\left[\begin{array}{l}
x_{e}(t+1) \\
v_{e}(t+1)
\end{array}\right]=\left[\begin{array}{cc}
F & 0 \\
-C F & 1
\end{array}\right]\left[\begin{array}{l}
x_{E}(t) \\
v_{E}(t)
\end{array}\right]+\left[\begin{array}{c}
G \\
-C G
\end{array}\right] u_{e}(t)
$$

$$
u_{e}(t)=-K x_{E}(t)+K_{1} v_{E}(t)=-\left[\begin{array}{ll}
K & K_{1}
\end{array}\right]\left[\begin{array}{l}
x_{E}(t) \\
v_{E}(t)
\end{array}\right]
$$


Sehingga dapat didefinisikan

$$
\begin{gathered}
\hat{F}=\left[\begin{array}{cc}
F & 0 \\
-C F & 1
\end{array}\right], \quad \hat{G}=\left[\begin{array}{c}
G \\
-C G
\end{array}\right], \quad \widehat{K}=-\left[\begin{array}{ll}
K & K_{1}
\end{array}\right] \\
w(t)=u_{E}(t), \quad \xi(t)=\left[\begin{array}{l}
x_{e}(t) \\
v_{e}(t)
\end{array}\right]=\left[\begin{array}{l}
x_{1_{E}}(t) \\
x_{2_{E}}(t) \\
x_{3_{E}}(t) \\
x_{4_{E}}(t) \\
v_{E}(t)
\end{array}\right]
\end{gathered}
$$

Maka representasi ruang keadaan dari sistem dapat ditulis

dengan

$$
\begin{gathered}
\xi(t+1)=\hat{F} \xi(t)+\widehat{G} w(t) \\
w(t)=-\widehat{K} \xi(t)
\end{gathered}
$$

$$
\hat{F}=\left[\begin{array}{cccc}
1.1048 & 0.1035 & 0 & 0 \\
2.1316 & 1.1048 & 0 & 0 \\
-0.0025 & -0.0001 & 1 & 0.1 \\
-0.0508 & -0.0025 & 0 & 1
\end{array}\right], \quad \hat{G}=\left[\begin{array}{c}
-0.0051 \\
-0.1035 \\
0.0025 \\
0.0501 \\
-0.0025
\end{array}\right]
$$

Perhatikan bahwa representasi awal sistem pendulum terbalik berada pada waktu kontinu, maka harus dipertimbangkan suatu indeks performansi waktu kontinu. Indeks performansi waktu kontinu berbentuk

$$
J=\int_{0}^{\infty}\left[\xi^{*}(t) Q \xi(t)+w^{*}(t) R w(t)\right] d t
$$

Indeks performansi tersebut didiskritkan menjadi

Ambil

$$
J=\sum_{t=0}^{\infty}\left[\xi(t)^{*} Q \xi(t)+w(t)^{*} R w(t)\right]
$$

$$
Q=\left[\begin{array}{ccccc}
10 & 0 & 0 & 0 & 0 \\
0 & 1 & 0 & 0 & 0 \\
0 & 0 & 100 & 0 & 0 \\
0 & 0 & 0 & 1 & 0 \\
0 & 0 & 0 & 0 & 1
\end{array}\right], \quad R=1
$$

Dapat diperoleh matriks gain umpan balik $K$ dan konstanta gain integral $K_{1}$ sebagai berikut

$$
K=\left[\begin{array}{llll}
-116.5430 & -74.1883 & -17.2665 & -20.0594
\end{array}\right], \quad K_{1}=\left[\begin{array}{l}
-0.6623
\end{array}\right]
$$

Dari matriks gain $K$ yang diketahui dapat diperoleh respon tangga satuan dengan cara sebagai berikut. Karena

maka

$$
u(t)=-K x(t)+K_{1} v(t)
$$

$$
\begin{aligned}
{\left[\begin{array}{c}
x(t+1) \\
v(t+1)
\end{array}\right] } & =F F\left[\begin{array}{l}
x(t) \\
v(t)
\end{array}\right]+G G r \\
y(t) & =\left[\begin{array}{ll}
C & 0
\end{array}\right]\left[\begin{array}{l}
x(t) \\
v(t)
\end{array}\right]
\end{aligned}
$$

dengan $r=1$. Definisikan

$$
\begin{aligned}
& F F=\left[\begin{array}{cc}
F-G K & G K_{1} \\
-C F+C G K & -C G K_{1}+1
\end{array}\right], \quad G G=\left[\begin{array}{l}
0 \\
1
\end{array}\right] \\
& C C=\left[\begin{array}{ll}
C & 0
\end{array}\right]=\left[\begin{array}{lllll}
0 & 0 & 1 & 0 & 0
\end{array}\right]
\end{aligned}
$$

Untuk mendapatkan response $x_{1}(t)$, notasikan

dengan mendefinisikan

$$
x_{1}(t)=\left[\begin{array}{lllll}
1 & 0 & 0 & 0 & 0
\end{array}\right]\left[\begin{array}{l}
x(t) \\
v(t)
\end{array}\right]
$$

$$
H H=\left[\begin{array}{lllll}
1 & 0 & 0 & 0 & 0
\end{array}\right]
$$


Konversikan persamaan ruang keadaan (3.11) dan (3.12) ke fungsi transfer $\frac{X_{1}(z)}{R(z)}$ dengan

$$
[\text { num } 1, \operatorname{den} 1]=\operatorname{ss} 2 t f(F F, G G, H H, 0)
$$

Kemudian gunakan perintah filter untuk mendapatkan respon tangga

$$
x_{1}=\text { filter }(\text { num } 1, \operatorname{den} 1, r)
$$

Dengan cara sama, untuk mendapatkan $x_{2}(t), x_{3}(t)=y(t), x_{4}(t)$, dan $x_{5}(t)=v(t)$, kalikan basis liniernya dengan $\left[\begin{array}{l}x(t) \\ v(t)\end{array}\right]$ dengan mendefinisikan basis linier tersebut sebagai

$$
\begin{gathered}
J J=\left[\begin{array}{lllll}
0 & 1 & 0 & 0 & 0
\end{array}\right] \\
C C=\left[\begin{array}{lllll}
0 & 0 & 1 & 0 & 0
\end{array}\right] \\
L L=\left[\begin{array}{lllll}
0 & 0 & 0 & 1 & 0
\end{array}\right] \\
M M=\left[\begin{array}{lllll}
0 & 0 & 0 & 0 & 1
\end{array}\right]
\end{gathered}
$$

Selanjutnya dilakukan hal yang sama untuk $\frac{X_{2}(t)}{R(t)}, \frac{Y(t)}{R(t)}, \frac{X_{4}(z)}{R(z)}$, dan $\frac{V(z)}{R(z)}$.

Plot respon tangga satuan versus $t$ ditunjukkan pada gambar berikut

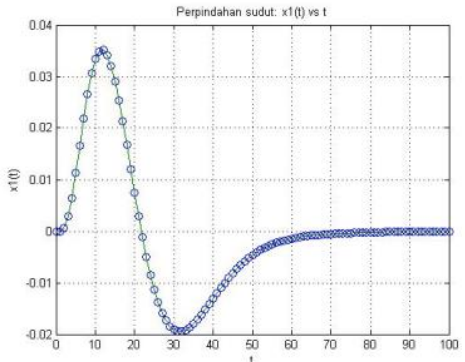

Gambar 3. Grafik Respon Tangga Satuan $x_{1}(t)$ versus $t$

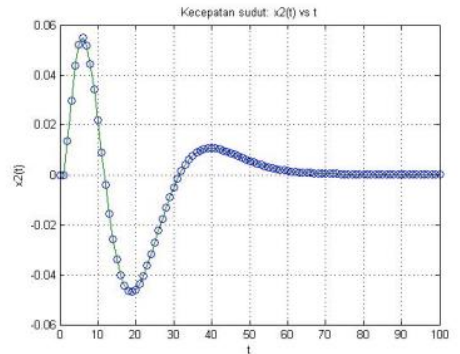

Gambar 4. Grafik Respon Tangga Satuan $x_{2}(t)$ versus $t$

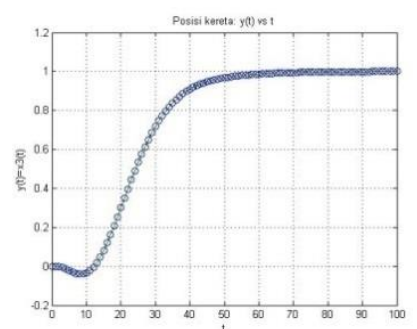

Gambar 5. Grafik Respon Tangga Satuan $x_{3}(t)$ versus $t$ 


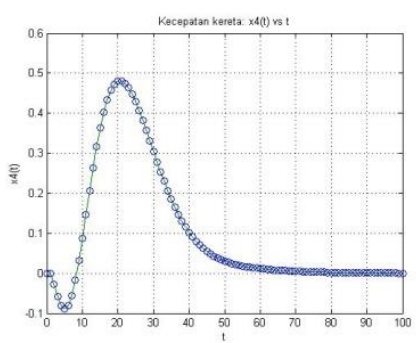

Gambar 6. Grafik Respon Tangga Satuan $x_{4}(t)$ versus $t$

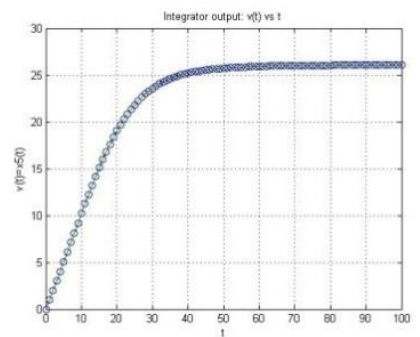

Gambar 7. Grafik Respon Tangga Satuan $x_{5}(t)$ versus $t$

Jika dimisalkan periode sampel adalah 0.1 detik, maka dari gambar di atas didapat bahwa keadaan steady state tercapai saat 7 detik.

\section{Kesimpulan}

1. Persamaan keadaan dan output dari sistem pendulum terbalik berbentuk persamaan kontinu dengan indeks performansi kontinu, pendiskritan dilakukan untuk membentuk suatu sistem linier invariant waktu diskrit dari sistem.

2. Desain servo diselesaikan dengan mendapatkan penyelesaian PRAWD $P$, matriks $K$ dan konstanta integral $K_{1}$ dari persamaan ruang keadaan

$$
\begin{gathered}
\xi(t+1)=\hat{F} \xi(t)+\hat{G} w(t) \\
w(t)=-\widehat{K} \xi(t)
\end{gathered}
$$

3. Dari matriks $K$ dan $K_{1}$ dapat diperoleh respon tangga satuan $x_{1}(t), x_{2}(t), x_{3}(t)=y(t), \quad x_{4}(t), \quad$ dan $x_{5}(t)=y(t)$. Kemudian dapat diberikan grafiknya versus $t$ dengan menggunakan software MATLAB.

\section{Daftar Pustaka}

[1] Bellon, J. (2008) "Riccati Equations in Optimal Control Theory". Mathematics Theses, Georgia State University.

[2] Clements, D. J., Wimmer, H.K. (2003). "Existence and Uniqueness of Unmixed Solutions of the Discrete-time Algebraic Riccati Equations". Systems and Control Letters, Vol. 50, Hal 343-340.

[3] Ogata, K. (1995). "Discrete-Time Control System". Prentice-Hall International, London.

[4] Subiono. (2010). "Matematika Sistem". Jurusan Matematika, FMIPA ITS. 